\title{
Mechanochemical Synthesis and Characterization of Nanocrystalline Copper-Cobalt Ferrites
}

\author{
Nikolay Velinov • Dimitar Dimitrov $\cdot$ Kremena Koleva $\cdot$ Krassimir Ivanov $\cdot$ Ivan Mitov
}

Received: 13 May 2014/Revised: 24 August 2014/Published online: 13 January 2015

(C) The Chinese Society for Metals and Springer-Verlag Berlin Heidelberg 2015

\begin{abstract}
Nanocrystalline copper-cobalt ferrites with composition $\mathrm{Cu}_{1-x} \mathrm{Co}_{x} \mathrm{Fe}_{2} \mathrm{O}_{4}$, where $x=0.2$ and 0.8 , were synthesized by mechanochemical treatment of co-precipitated precursors. The ferrite powders were characterized by XRD and Mössbauer spectroscopy. Results proved obtaining of spinel ferrites with crystallite size smaller than $10 \mathrm{~nm}$. Increasing of crystallite size of samples with increasing of mechanochemical treatment duration was established, too. Catalytic properties of obtained ferrites were tested in reactions of oxidation of $\mathrm{CO}$, methanol and dimethyl ether. High catalytic activity of nanocrystalline copper-cobalt ferrites toward $\mathrm{CO}$ and $\mathrm{CH}_{3} \mathrm{OH}$ (about $100 \%$ conversions of $\mathrm{CO}$ and $\mathrm{CH}_{3} \mathrm{OH}$ at $160{ }^{\circ} \mathrm{C}$ ) and moderate activity toward $\left(\mathrm{CH}_{3}\right)_{2} \mathrm{O}$ oxidation were established. The results obtained revealed that the $\mathrm{Co} / \mathrm{Cu}$ atomic ratio is an important factor determinant the behavior of catalysts toward methanol and DME oxidation.
\end{abstract}

KEY WORDS: Mechanochemical synthesis; Nanocrystalline; Ferrites; Mössbauer spectroscopy; Catalysis

\section{Introduction}

Nanostructured ferrite materials are topics of many scientific investigations due to their potential application in biology, electronics and catalysis [1]. Spinel mixed oxide ferrites with general formula $A B_{2} \mathrm{O}_{4}$ are denoted as normal spinel if all $2+$ cations occupy the tetrahedral positions, and inverse spinel, if half of $3+$ ions occupy tetrahedral positions and the other half and $2+$ cations lie over the octahedral position. In low defective spinel ferrite phases, $\mathrm{Cu}^{2+}$ and $\mathrm{Co}^{2+}$ are known to have a preference for octahedral sites while half of $\mathrm{Fe}^{3+}$ occupies tetrahedral sites

Available online at http://link.springer.com/journal/40195

N. Velinov $(\bowtie) \cdot$ K. Koleva $\cdot$ I. Mitov

Institute of Catalysis, Bulgarian Academy of Sciences, Acad.

G. Bonchev Str., bl. 11, 1113 Sofia, Bulgaria

e-mail: nikivelinov@ic.bas.bg

D. Dimitrov $\cdot$ K. Ivanov

Department of Chemistry, Agricultural University,

12 Mendeleev Str., 4000 Plovdiv, Bulgaria
[2]. In case of low-temperature synthesis or methods of synthesis at highly nonequilibrium conditions, high vacancy densities and variations in the site population could be obtained [3,4]. Mechanochemistry is a method based on nonequilibrium treatment conditions of materials and recently has been applied to initiate changes of particle size, appearance of defects (structural disorder, lattice strains, excitation and migrations of defects, formation of vacancies), structural transformations (polymorphous conversions, partial or complete amorphization, changes of coordination state of ion) and changes in the phase composition [5]. These opportunities of the method make it attractive for using to obtain materials with well-known compositions but with new structure and properties. Mechanochemistry has been recently considered as perspective method for preparation of catalysts because of its effectiveness and even advantages compared to standard methods for catalysts preparation [6]. Nanocrystalline spinel oxides have been appropriately synthesized starting from various precursors with layered double hydroxide (LDH) structure as hydroxide-carbonates [1, 7-11], hydroxide-chlorides [12], etc. The structure and functional 
properties of synthesized oxides starting from LDH have been observed to be related to the nature (e.g., thermal, spark plasma sintering, mechanochemical) and conditions of treatment of precursors [10,11].

The technology of removal of $\mathrm{CO}$ and volatile organic compounds (VOCs) emitted from variety of industrial processes by catalytic total oxidation has been recently discussed as most promising [13, 14]. The most commonly used in automotive and industrial catalytic converter catalysts are based on supported noble metals [15, 16]. Recently, nanostructured metal oxides, mainly of transition metals, have been investigated as alternative catalysts, because of the advantage of having lower cost, higher thermal stability and greater resistance to deactivation by poisoning [16-18].

The aim of current work is to investigate possibility of synthesis of nanocrystalline $\mathrm{Cu}-\mathrm{Co}$ ferrites by mechanochemical treatment of co-precipitated precursors. Testing of catalytic properties of obtained ferrites with different $\mathrm{Cu} / \mathrm{Co}$ ratio in reactions of oxidation of $\mathrm{CO}$, methanol and dimethyl ether is also object of this study.

\section{Experimental}

Copper-cobalt ferrites with composition $\mathrm{Cu}_{1-x} \mathrm{Co}_{x} \mathrm{Fe}_{2} \mathrm{O}_{4}$, where $x=0.2$ and 0.8 , were prepared by two-step procedure of co-precipitation and mechanochemical treatment. The starting mixed solution of $\mathrm{Cu}\left(\mathrm{NO}_{3}\right)_{2} \cdot 3 \mathrm{H}_{2} \mathrm{O}, \mathrm{Co}\left(\mathrm{NO}_{3}\right)_{2} \cdot 6 \mathrm{H}_{2} \mathrm{O}$ and $\mathrm{Fe}\left(\mathrm{NO}_{3}\right)_{3} \cdot 9 \mathrm{H}_{2} \mathrm{O}$ was precipitated with drop-wise addition of $1 \mathrm{~mol} / \mathrm{L}$ sodium carbonate up to $\mathrm{pH}=9$ under continuous stirring. The initially obtained precipitate was dried at room temperature (RT) to form precursor powder $\left(\mathrm{Cu}_{1-}\right.$ ${ }_{x} \mathrm{Co}_{x} \mathrm{Fe}_{2} \mathrm{O}_{4}$ - $\mathrm{HC}$ ). At the second step of mechanochemical synthesis, the obtained precursor powder was milled using a Fritsch planetary miller in a hardened steel vial. The balls-topowder mass ratio was 10:1. The mechanochemical treated samples are denoted $\mathrm{Cu}_{1-x} \mathrm{Co}_{x} \mathrm{Fe}_{2}-\mathrm{MS} y$, where $y=1$ and 2 is the duration of treatment in hours.

The powder XRD patterns were recorded by use of a TUR M62 diffractometer with $\mathrm{Co} K_{\alpha}$ radiation. The observed patterns were cross-matched with those in the JCPDS database. The Mössbauer spectra were obtained at RT and liquid nitrogen temperature (LNT) with a Wissel electromechanical spectrometer (Wissenschaftliche Elektronik $\mathrm{GmbH}$, Germany) working in a constant acceleration mode, and $\alpha$-Fe standard were used. The experimentally obtained spectra were fitted using CONFIT2000 software [19]. The parameters of hyperfine interaction such as isomer shift $(\delta)$, quadrupole splitting $(\Delta)$, effective internal magnetic field $(B)$, line widths $\left(\Gamma_{\exp }\right)$ and relative weight $(G)$ of the partial components in the spectra were determined.
The catalytic activity of the samples in $\mathrm{CO}$ and $\mathrm{CH}_{3} \mathrm{OH}$ oxidation was measured using continuous flow equipment with fixed-bed stainless steel reactor at atmospheric pressure. The following conditions were chosen: Catalyst bed volume is $0.5 \mathrm{~cm}^{3}$ (particle size is $0.3-0.6 \mathrm{~mm}$ ), and inlet $\mathrm{CO}$ and $\mathrm{CH}_{3} \mathrm{OH}$ concentrations are 2.0 vol\% balanced with air and space velocity of $20,000 \mathrm{~h}^{-1}$. Two types of equipments for $\left(\mathrm{CH}_{3}\right)_{2} \mathrm{O}$ oxidation measurements were used: (1) flow-line equipment with an isothermal reactor, allowing precise control of the methanol dehydration to $\left(\mathrm{CH}_{3}\right)_{2} \mathrm{O}$ on $\mathrm{Al}_{2} \mathrm{O}_{3}$ and (2) flow-line equipment with stainless steel reactor for deep oxidation of the preliminarily purified $\left(\mathrm{CH}_{3}\right)_{2} \mathrm{O}$. Detailed description is given in Ref. [20]. The feed gas was $1.0 \mathrm{vol} \%\left(\mathrm{CH}_{3}\right)_{2} \mathrm{O}$ balanced with air, and the space velocity was $20,000 \mathrm{~h}^{-1}$. The reactant and product gases were analyzed for methanol, $\left(\mathrm{CH}_{3}\right)_{2} \mathrm{O}, \mathrm{CO}, \mathrm{CO}_{2}, \mathrm{O}_{2}$ and $\mathrm{N}_{2}$ by HP 5890 series II gas chromatograph, equipped with flame ionization and thermal conductivity detectors and Porapak Q and MS-5A columns.

\section{Results and Discussion}

XRD patterns of the obtained samples are presented in Fig. 1. The spectrum of obtained Co-reach precursor powders has a typical for hydrotalcite-like structure X-ray pattern, as found for hydrotalcite (PDF 70-2151) or iron carbonate hydroxide (PDF 46-0098). It is seen that the degree of crystallinity of the sample with lower cobalt content is lower and its XRD pattern looks like two-line ferrihydrite. XRD patterns of samples after mechanochemical treatments are characterized with broad reflection lines corresponding to cubic spinel ferrite phases. The broadness of diffraction peaks could be explained with presence of nanosized crystallites $(<10 \mathrm{~nm})$ and high degree of defects in the crystal structure. Similar diffraction patterns have been observed of mechanochemically synthesized spinel ferrites $[9,11]$.

Mössbauer spectra of mechanochemically synthesized ferrites recorded at RT and LNT are presented in Figs. 2 and 3. At RT, spectra of the samples are consisting of doublet components. Calculated parameters of fitted components of spectra are presented in Table 1. Parameters of doublets are typical for $\mathrm{Fe}^{3+}$ ions occupying octahedral and tetrahedral coordinated positions in ferrite particles with superparamagnetic behavior. Appearance of about 5\% sextet components in $\mathrm{Cu}_{0.8} \mathrm{Co}_{0.2} \mathrm{Fe}_{2} \mathrm{O}_{4}$-MS2 spectrum is due to increasing of ferrite particle size and formation of ferrimagnetic particles during mechanochemical treatment [9]. The correlation of the duration of mechanochemical treatment on increasing of the crystallite size of ferrites could be seen in Mössbauer spectra recorded at LNT, 
$\begin{array}{ll}\text { (a) } & \text { Ferrite structure } \mathrm{CoFe}_{2} \mathrm{O}_{4} \text { (PDF 03-0864) } \\ \circ & \text { Hydrotalcite-like structure }\end{array}$
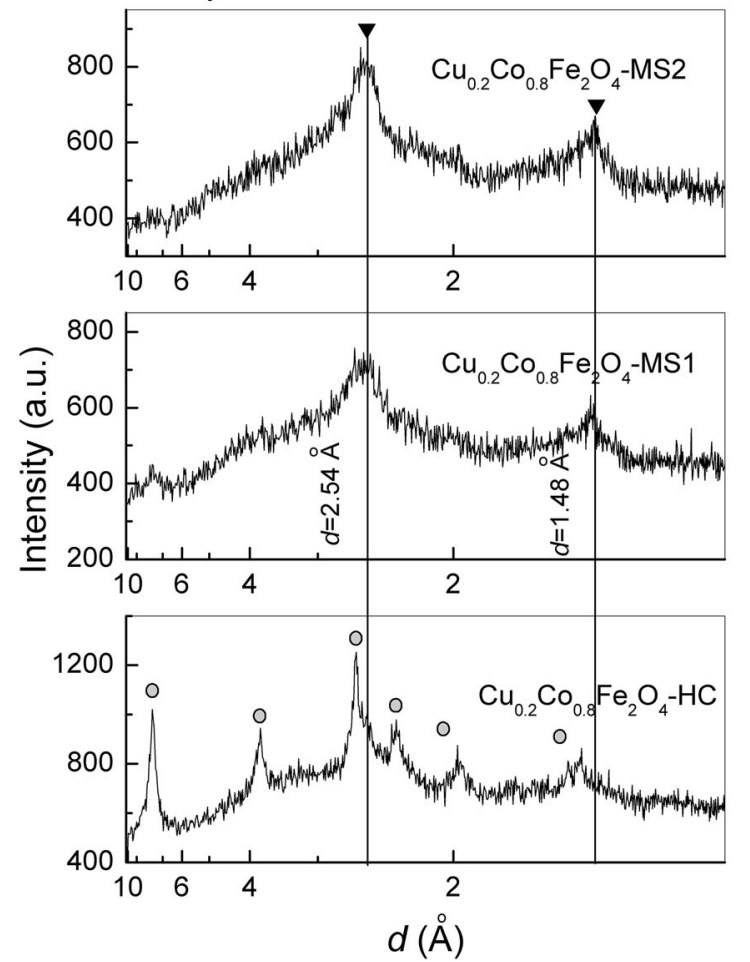

(b) $\quad$ Ferrite structure $\mathrm{CuFe}_{2} \mathrm{O}_{4}(\mathrm{PDF} 77-0427)$
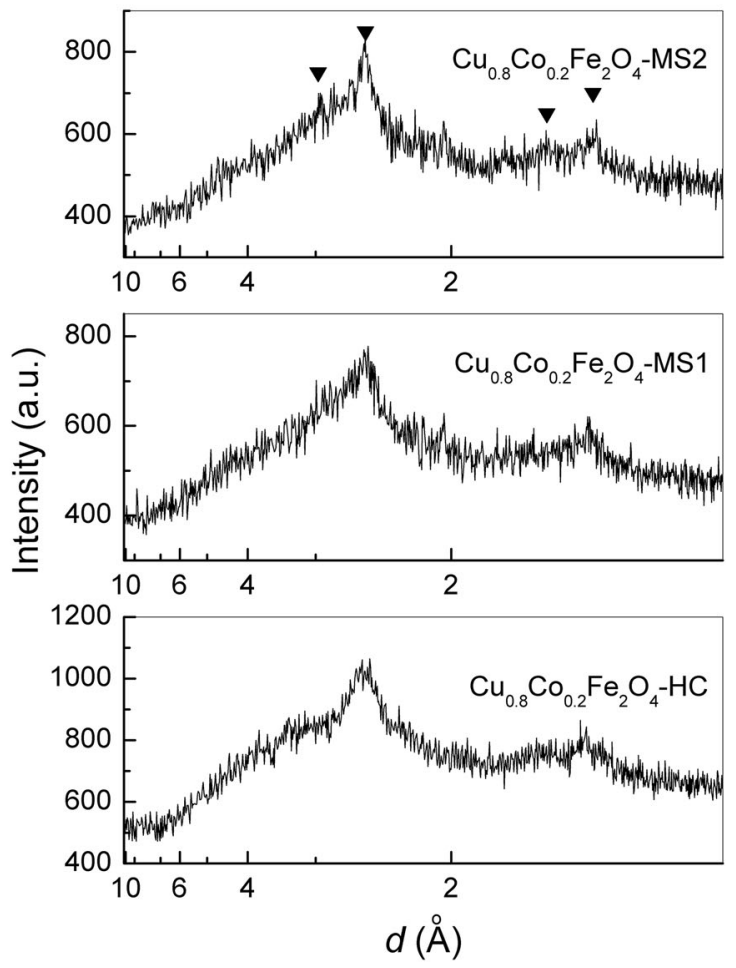

Fig. 1 XRD patterns of synthesized $\mathrm{Cu}_{0.2} \mathrm{Co}_{0.8} \mathrm{Fe}_{2} \mathrm{O}_{4}$ a, $\mathrm{Cu}_{0.8} \mathrm{Co}_{0.2} \mathrm{Fe}_{2} \mathrm{O}_{4}$ b ferrites
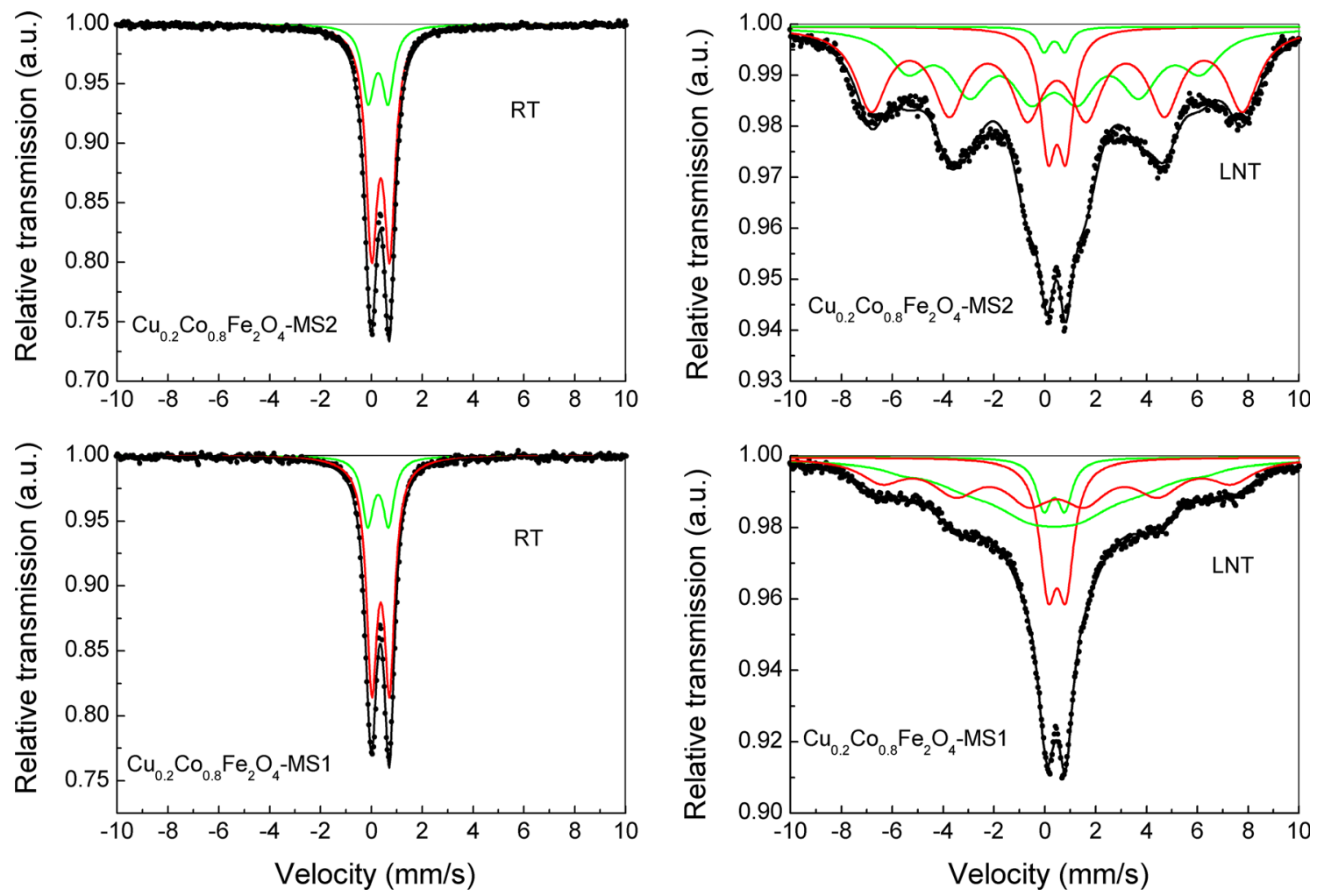

Fig. 2 Mössbauer spectra of $\mathrm{Cu}_{0.2} \mathrm{Co}_{0.8} \mathrm{Fe}_{2} \mathrm{O}_{4}$ ferrites at RT and LNT 

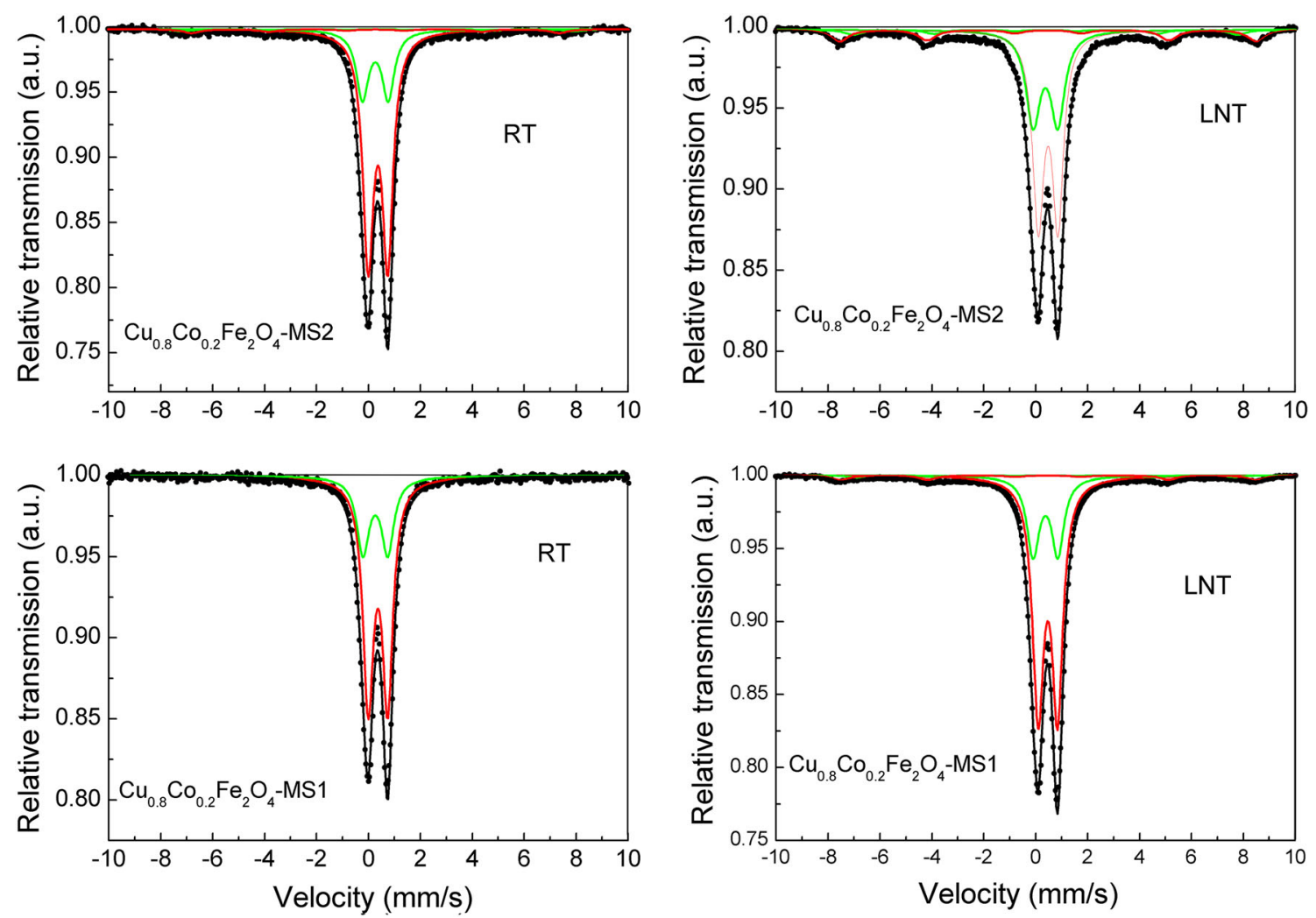

Fig. 3 Mössbauer spectra of $\mathrm{Cu}_{0.8} \mathrm{Co}_{0.2} \mathrm{Fe}_{2} \mathrm{O}_{4}$ ferrites at RT and LNT

where the increasing of sextet components' presence is evident. From data obtained after spectra, fitting could be concluded that superparamagnetic blocking temperature for samples with compositions $\mathrm{Cu}_{0.2} \mathrm{Co}_{0.8} \mathrm{Fe}_{2} \mathrm{O}_{4}$ is between RT and LNT for both mechanochemical treatment. The blocking temperature for $\mathrm{Cu}_{0.8} \mathrm{Co}_{0.2} \mathrm{Fe}_{2} \mathrm{O}_{4}$ samples is below LNT, as the sextet components are calculated of 7 and 16\% at LNT for MS1 and MS2 samples, respectively. This is not surprising, because of facilitated ferrite formation of composition with higher Co content, as has been proved by TG-DSC, XRD and Mössbauer spectroscopy investigations in previous work [1].

Figure 4 compares the catalytic performance in terms of $\mathrm{CO}$ conversion degree of the catalysts versus reaction temperature. Measurable oxidation begins at $50{ }^{\circ} \mathrm{C}$ for all catalysts. Their activity increased rapidly with increasing temperature, and the samples attained almost complete conversion at $160^{\circ} \mathrm{C}$. No significant difference can be seen despite of essential difference in catalyst composition and preparation procedure. The results can be explained by the fact that both $\mathrm{CuO}$ and $\mathrm{Co}_{3} \mathrm{O}_{4}$ single catalysts are excellent low-temperature oxidation catalysts [21]. Based on the experimental results and the results of other authors, we can hypothesize that the iron compounds act as an inert diluents. Firsova et al. [22] investigated CO oxidation on
$\mathrm{Fe}_{2} \mathrm{O}_{3}$ and mixed $\mathrm{Cu}-\mathrm{Fe}$ zirconium-supported samples and found that very low conversion $\left(34 \%\right.$ at $\left.290{ }^{\circ} \mathrm{C}\right)$ was observed on $10 \% \mathrm{Fe}_{2} \mathrm{O}_{3} / \mathrm{ZrO}_{2}$. The catalytic properties of $\mathrm{CuO} / \mathrm{Fe}_{2} \mathrm{O}_{3} / \mathrm{ZrO}_{2}$ were also identical to those of $\mathrm{CuO} / \mathrm{ZrO}_{2}$, and they depended on the presence of $\mathrm{Cu}-\mathrm{O}-\mathrm{Zr}$ clusters on the surface only. The some authors concluded that addition of cobalt to $\mathrm{Cu}-\mathrm{Ce}-\mathrm{O}$ can improve the dispersion of copper species and enhance the reducibility of the catalyst, and the presence of the copper can also favor the reducibility of the cobalt species. The synergetic interaction between copper, cobalt and ceria species would promote the catalytic activity of the catalyst for $\mathrm{CO}$ oxidation. This assumption is also confirmed by the results in Fig. 4. The activity of the mixed catalyst significantly exceeds that of the pure $\mathrm{CuO}$ under the same conditions of conducting the $\mathrm{CO}$ oxidation [20].

Somewhat different are the results for the oxidation of methanol on the mixed copper-cobalt catalysts (Fig. 5). In this case, $\mathrm{Cu} / \mathrm{Co}$ atomic ratio and the mechanochemical treatment have significant effect on the activities of the catalysts. Compared with $\mathrm{Cu}_{0.8} \mathrm{Co}_{0.2} \mathrm{Fe}_{2} \mathrm{O}_{4}$ catalyst, the $\mathrm{Cu}_{0.2} \mathrm{Co}_{0.8} \mathrm{Fe}_{2} \mathrm{O}_{4}$ samples have better activity.

Considerably different is the activity of the catalysts with respect to the DME oxidation. The temperature dependence of $\left(\mathrm{CH}_{3}\right)_{2} \mathrm{O}$ conversions is illustrated in Fig. 6 . 
Table 1 Parameters of Mössbauer spectra of the investigated samples at RT and LNT

\begin{tabular}{|c|c|c|c|c|c|c|}
\hline Sample & Components & $\delta(\mathrm{mm} / \mathrm{s})$ & $\Delta(\mathrm{mm} / \mathrm{s})$ & $B(\mathrm{~T})$ & $\Gamma_{\exp }(\mathrm{mm} / \mathrm{s})$ & $G(\%)$ \\
\hline \multirow[t]{2}{*}{$\mathrm{Cu}_{0.2} \mathrm{Co}_{0.8} \mathrm{Fe}_{2} \mathrm{O}_{4}-\mathrm{MS} 1$} & $\mathrm{Db} 1-\mathrm{Fe}_{\mathrm{octa}}^{3+}$ & 0.37 & 0.70 & - & 0.50 & 76 \\
\hline & $\mathrm{Db} 2-\mathrm{Fe}_{\text {tetra }}^{3+}$ & 0.27 & 0.82 & - & 0.53 & 24 \\
\hline \multirow[t]{2}{*}{$\mathrm{Cu}_{0.2} \mathrm{Co}_{0.8} \mathrm{Fe}_{2} \mathrm{O}_{4}-\mathrm{MS} 2$} & $\mathrm{Db} 1-\mathrm{Fe}_{\mathrm{octa}}^{3+}$ & 0.37 & 0.71 & - & 0.53 & 74 \\
\hline & $\mathrm{Db} 2-\mathrm{Fe}_{\text {tetra }}^{3+}$ & 0.27 & 0.79 & - & 0.56 & 26 \\
\hline \multirow[t]{2}{*}{$\mathrm{Cu}_{0.8} \mathrm{Co}_{0.2} \mathrm{Fe}_{2} \mathrm{O}_{4}-\mathrm{MS} 1$} & $\mathrm{Db} 1-\mathrm{Fe}_{\mathrm{octa}}^{3+}$ & 0.37 & 0.75 & - & 0.49 & 72 \\
\hline & $\mathrm{Db} 2-\mathrm{Fe}_{\text {tetra }}^{3+}$ & 0.27 & 0.95 & - & 0.57 & 28 \\
\hline \multirow[t]{4}{*}{$\mathrm{Cu}_{0.8} \mathrm{Co}_{0.2} \mathrm{Fe}_{2} \mathrm{O}_{4}-\mathrm{MS} 2$} & $\mathrm{Sx} 1-\mathrm{Fe}_{\mathrm{octa}}^{3+}$ & 0.37 & 0.00 & 47.0 & 0.75 & 3 \\
\hline & $\mathrm{Sx} 2-\mathrm{Fe}_{\text {tetra }}^{3+}$ & 0.27 & 0.00 & 44.0 & 0.75 & 2 \\
\hline & $\mathrm{Db} 1-\mathrm{Fe}_{\mathrm{octa}}^{3+}$ & 0.37 & 0.75 & - & 0.50 & 71 \\
\hline & $\mathrm{Db} 2-\mathrm{Fe}_{\text {tetra }}^{3+}$ & 0.27 & 0.99 & - & 0.54 & 24 \\
\hline \multirow[t]{4}{*}{$\mathrm{Cu}_{0.2} \mathrm{Co}_{0.8} \mathrm{Fe}_{2} \mathrm{O}_{4}-\mathrm{MS} 1 \mathrm{LNT}$} & $\mathrm{Sx} 1-\mathrm{Fe}_{\mathrm{octa}}^{3+}$ & 0.48 & 0.00 & 42.8 & 2.00 & 36 \\
\hline & $\mathrm{Sx} 2-\mathrm{Fe}_{\text {tetra }}^{3+}$ & 0.38 & 0.00 & 37.0 & 1.90 & 40 \\
\hline & $\mathrm{Db} 1-\mathrm{Fe}_{\mathrm{octa}}^{3+}$ & 0.48 & 0.70 & - & 0.78 & 18 \\
\hline & $\mathrm{Db} 2-\mathrm{Fe}_{\text {tetra }}^{3+}$ & 0.38 & 0.82 & - & 0.70 & 6 \\
\hline \multirow[t]{4}{*}{$\mathrm{Cu}_{0.2} \mathrm{Co}_{0.8} \mathrm{Fe}_{2} \mathrm{O}_{4}-\mathrm{MS} 2 \mathrm{LNT}$} & $\mathrm{Sx} 1-\mathrm{Fe}_{\mathrm{octa}}^{3+}$ & 0.48 & 0.00 & 45.4 & 1.05 & 49 \\
\hline & $\mathrm{Sx} 2-\mathrm{Fe}_{\text {tetra }}^{3+}$ & 0.38 & 0.00 & 37.7 & 1.50 & 38 \\
\hline & $\mathrm{Db} 1-\mathrm{Fe}_{\mathrm{octa}}^{3+}$ & 0.48 & 0.70 & - & 0.72 & 11 \\
\hline & $\mathrm{Db} 2-\mathrm{Fe}_{\text {tetra }}^{3+}$ & 0.38 & 0.82 & - & 0.55 & 2 \\
\hline \multirow[t]{4}{*}{$\mathrm{Cu}_{0.8} \mathrm{Co}_{0.2} \mathrm{Fe}_{2} \mathrm{O}_{4}-\mathrm{MS} 1 \mathrm{LNT}$} & $\mathrm{Sx} 1-\mathrm{Fe}_{\mathrm{octa}}^{3+}$ & 0.48 & 0.00 & 49.7 & 0.80 & 5 \\
\hline & $\mathrm{Sx} 2-\mathrm{Fe}_{\text {tetra }}^{3+}$ & 0.38 & 0.00 & 45.0 & 0.80 & 2 \\
\hline & $\mathrm{Db} 1-\mathrm{Fe}_{\mathrm{octa}}^{3+}$ & 0.48 & 0.75 & - & 0.51 & 68 \\
\hline & $\mathrm{Db} 2-\mathrm{Fe}_{\text {tetra }}^{3+}$ & 0.38 & 0.95 & - & 0.57 & 25 \\
\hline \multirow[t]{4}{*}{$\mathrm{Cu}_{0.8} \mathrm{Co}_{0.2} \mathrm{Fe}_{2} \mathrm{O}_{4}-\mathrm{MS} 2 \mathrm{LNT}$} & $\mathrm{Sx} 1-\mathrm{Fe}_{\mathrm{octa}}^{3+}$ & 0.48 & 0.00 & 49.9 & 0.80 & 11 \\
\hline & $\mathrm{Sx} 2-\mathrm{Fe}_{\text {tetra }}^{3+}$ & 0.38 & 0.00 & 46.0 & 0.80 & 5 \\
\hline & $\mathrm{Db} 1-\mathrm{Fe}_{\mathrm{octa}}^{3+}$ & 0.48 & 0.76 & - & 0.51 & 52 \\
\hline & $\mathrm{Db} 2-\mathrm{Fe}_{\text {tetra }}^{3+}$ & 0.38 & 0.95 & - & 0.65 & 32 \\
\hline
\end{tabular}

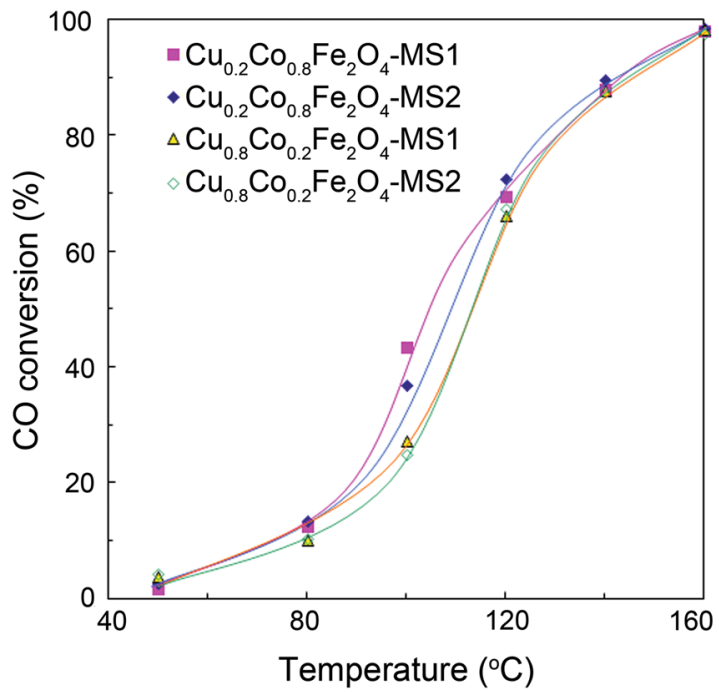

Fig. 4 Temperature dependence of CO conversion degree over the catalysts

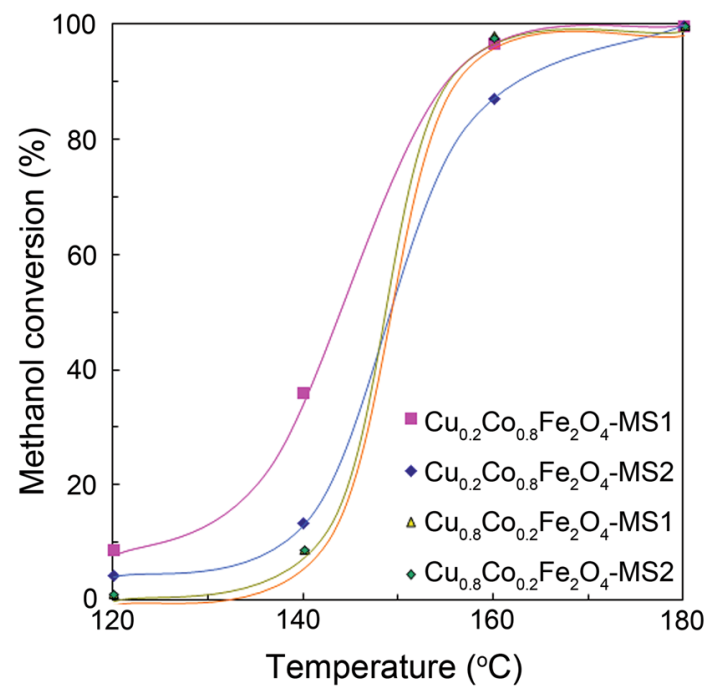

Fig. 5 Temperature dependence of methanol conversion degree over the catalysts 


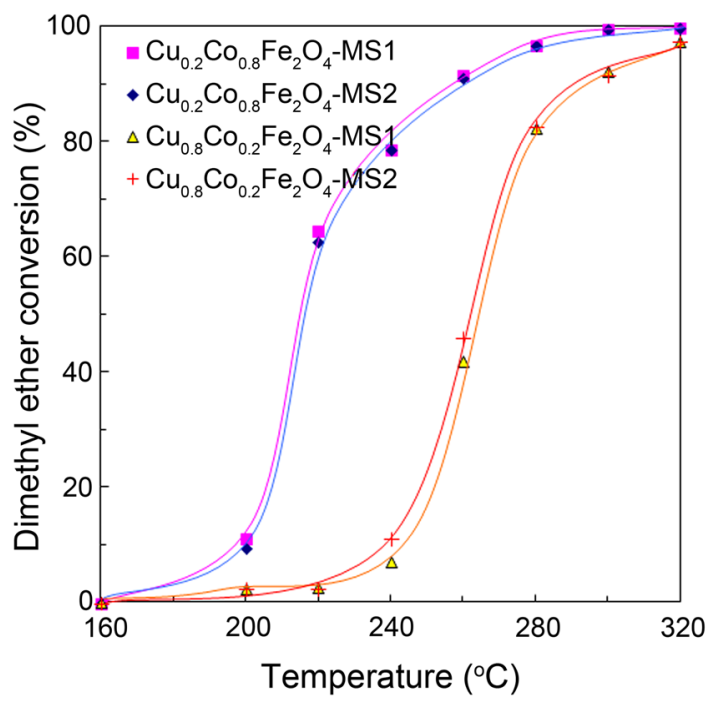

Fig. 6 Temperature dependence of dimethyl ether conversion degree over the catalysts

The only product of the oxidation is $\mathrm{CO}_{2}$, and measurable oxidation begins at $160{ }^{\circ} \mathrm{C}$ for $\mathrm{Cu}_{0.2} \mathrm{Co}_{0.8} \mathrm{Fe}_{2} \mathrm{O}_{4}$ catalysts. Their activity increased rapidly with increasing temperature and reached complete $\mathrm{CO}$ conversion at $290{ }^{\circ} \mathrm{C}$. $\mathrm{Cu}_{0.8} \mathrm{Co}_{0.2} \mathrm{Fe}_{2} \mathrm{O}_{4}$ samples demonstrated low ability to oxidize $\left(\mathrm{CH}_{3}\right)_{2} \mathrm{O}$. The process begins at about $200{ }^{\circ} \mathrm{C}$ and complete conversion needs of temperature more than $330{ }^{\circ} \mathrm{C}$. Our experience has shown that the pure copper oxide has a low activity toward the oxidation of DME [20], which is confirmed by the results in Fig. 6. Obviously, in this case, the active component of the mixed $\mathrm{Cu}-\mathrm{Co}-\mathrm{Fe}$ catalysts is associated mainly with the cobalt species.

\section{Conclusions}

Nanocrystalline copper-cobalt ferrites were synthesized by mechanochemical treatment of co-precipitated precursors. Superparamagnetic behavior of synthesized ferrites was established by Mössbauer spectroscopy at RT and LNT, proving obtaining of ferrite crystallites with size under $10 \mathrm{~nm}$. The correlation of the duration of mechanochemical treatment on increasing of the crystallite size of ferrites was observed. The evaluation of catalytic performance evidenced high catalytic activity of mixed $\mathrm{Cu}-\mathrm{Co}-\mathrm{Fe}$ oxide toward $\mathrm{CO}$ and $\mathrm{CH}_{3} \mathrm{OH}$ (about $100 \%$ conversions of $\mathrm{CO}$ and $\mathrm{CH}_{3} \mathrm{OH}$ at $160{ }^{\circ} \mathrm{C}$ ) and moderate activity toward $\left(\mathrm{CH}_{3}\right)_{2} \mathrm{O}$ oxidation. The results obtained revealed that the $\mathrm{Co} / \mathrm{Cu}$ atomic ratio is an important factor determinant the behavior of the resulting catalysts toward methanol and DME oxidation.

Acknowledgments The present research work was sponsored by the Bulgarian National Science Fund under Project DDVU 02/07/ 2010. N.V. acknowledges gratefully financial support by the European Social Fund within the framework of Operating Program "Development of Human Resources" (BG051PO001-3.3.06-0050).

\section{References}

[1] N. Velinov, K. Koleva, T. Tsoncheva, D. Paneva, E. Manova, K. Tenchev, B. Kunev, I. Mitov, Cent. Eur. J. Chem. 12, 250 (2014)

[2] P.V. Kovtunenko, Glass Ceram. 54, 143 (1997)

[3] V. Rusanov, V. Gushterov, S. Nikolov, A.X. Trautwein, Hyperfine Interact. 191, 67 (2009)

[4] V. Sepelák, S. Indris, P. Heitjans, K.D. Becker, J. Alloys Compd. 434-435, 776 (2007)

[5] P. Baláž, M. Achimovičová, M. Baláž, P. Billik, Z. CherkezovaZheleva, J.M. Criado, F. Delogu, E. Dutková, E. Gaffet, F.J. Gotor, R. Kumar, I. Mitov, T. Rojac, M. Senna, A. Streletskii, K. Wieczorek-Ciurowa, Chem. Soc. Rev. 42, 7571 (2013)

[6] K. Ralphs, C. Hardacre, S.L. James, Chem. Soc. Rev. 42, 7701 (2013)

[7] H.B. Liu, Z.Y. Huang, B.Z. Guo, Q.Z. Jiao, Z.Y. Xiong, Acta Metall. Sin. (Engl. Lett.) 27, 211 (2014)

[8] T. Tsoncheva, E. Manova, N. Velinov, D. Paneva, M. Popova, B. Kunev, K. Tenchev, I. Mitov, Catal. Commun. 12, 105 (2010)

[9] E. Manova, T. Tsoncheva, D. Paneva, M. Popova, N. Velinov, B. Kunev, K. Tenchev, I. Mitov, J. Solid State Chem. 184, 1153 (2011)

[10] N. Velinov, E. Manova, T. Tsoncheva, C. Estournès, D. Paneva, K. Tenchev, V. Petkova, K. Koleva, B. Kunev, I. Mitov, Solid State Sci. 14, 1092 (2012)

[11] N. Velinov, K. Koleva, T. Tsoncheva, E. Manova, D. Paneva, K Tenchev, B. Kunev, I. Mitov, Catal. Commun. 32, 41 (2013)

[12] Z. Cherkezova-Zheleva, K. Zaharieva, V. Petkova, B. Kunev, I. Mitov, Bulg. Chem. Commun. 44, 24 (2012)

[13] P. Kaminski, I. Sobczak, P. Decyk, M. Ziolek, W.J. Roth, B. Campo, M. Daturi, J. Phys. Chem. C 117, 2147 (2013)

[14] T. Tabakova, D. Dimitrov, M. Manzoli, F. Vindigni, P. Petrova, L. Ilieva, R. Zanella, K. Ivanov, Catal. Commun. 35, 51 (2013)

[15] L. Matějová, P. Topka, K. Jirátová, O. Šolcová, Appl. Catal. A 443-444, 40 (2012)

[16] G. Salek, P. Alphonse, P. Dufour, S. Guillemet-Fritsch, C. Tenailleau, Appl. Catal. B 147, 1 (2014)

[17] S.A. Hosseini, M.C. Alvarez-Galvan, J.L.G. Fierro, A. Niaei, D. Salari, Ceram. Int. 39, 9253 (2013)

[18] S.A. Hosseini, A. Niaei, D. Salari, M.C. Alvarez-Galvan, J.L.G. Fierro, Ceram. Int. 40, 6157 (2014)

[19] T. Žák, Y. Jirásková, Surf. Interface Anal. 38, 710 (2006)

[20] K. Ivanov, D. Dimitrov, B. Boyanov, World Acad. Sci. Eng. Technol. 73, 428 (2011)

[21] Y. Su, S. Wang, T. Zhang, S. Wang, B. Zhu, J. Cao, Z. Yuan, S. Zhang, W. Huang, S. Wu, Catal. Lett. 124, 405 (2008)

[22] A.A. Firsova, T.I. Khomenko, O.N. Sil'chenkova, V.N. Korchak, Kinet. Catal. 51, 299 (2010) 